\title{
Evaluation of exercise capacity with cardiopulmonary exercise testing and BNP levels in adult patients with single or systemic right ventricles
}

\author{
Olga Trojnarska, Adrian Gwizdała, Sławomir Katarzyński, Agnieszka Katarzyńska, \\ Zofia Oko-Sarnowska, Piotr Bręborowicz, Stefan Grajek
}

$1^{\text {st }}$ Cardiology Department, University of Medical Sciences, Poznan, Poland

Submitted: 21 October 2008

Accepted: 12 February 2009

Arch Med Sci 2010; 6, 2: 192-197

DOI: 10.5114/aoms.2010.13893

Copyright @ 2010 Termedia \& Banach

\begin{abstract}
Introduction: The aim of the study was to evaluate exercise capacity using cardiopulmonary exercise test (CPET) and serum B-type natriuretic peptide (BNP) levels in patients with single or systemic right ventricles.

Material and methods: The study group included 40 patients (16 males) - 17 with transposition of the great arteries after Senning operation, 13 with corrected transposition of the great arteries and 10 with single ventricle after Fontan operation, aged $19-55$ years (mean $28.8 \pm 9.5$ years). The control group included 22 healthy individuals (10 males) aged $23-49$ years (mean $30.6 \pm 6.1$ years). Results: The majority of patients reported good exercise tolerance - accordingly 27 were classified in NYHA class I (67.5\%), 12 (30\%) in class II, and only 1 (0.5\%) in class III. Cardiopulmonary exercise test revealed significantly lower exercise capacity in study patients than in control subjects. In the study vs. control group $\mathrm{VO}_{2 \max }$ was $21.7 \pm 5.9$ vs. $34.2 \pm 7.4 \mathrm{ml} / \mathrm{kg} / \mathrm{min}(p=0.00001)$, maximum heart rate at peak exercise (HRmax) $152.5 \pm 32.3$ vs. $187.2 \pm 15.6 \mathrm{bpm}(p=0.00001)$, $\mathrm{VE} / \mathrm{VCO}_{2}$ slope $34.8 \pm 7.1$ vs. $25.7 \pm 3.2(p=0.00001)$, forced vital capacity (FVC) $3.7 \pm 0.91$ vs. $4.6 \pm 0.3(p=0.03)$, forced expiratory volume in $1 \mathrm{~s}\left(\mathrm{FEV}_{1}\right)$ $3.0 \pm 0.7$ vs. $3.7 \pm 0.91(p=0.0002)$ respectively. Serum BNP concentrations were higher in study patients than in control subjects; $71.8 \pm 74.4$ vs. $10.7 \pm 8.1(\mathrm{pg} / \mathrm{ml})$ respectively $(p=0.00001)$. No significant correlations between BNP levels and CPET parameters were found.

Conclusions: Patients with a morphological right ventricle serving the systemic circulation and those with common ventricle physiology after Fontan operation show markedly reduced exercise capacity. They are also characterized by higher serum BNP concentrations, which do not however correlate with CPET parameters.
\end{abstract}

Key words: B-type natriuretic peptide, heart failure, grown up congenital heart disease, common ventricle, Senning/Mustard operation, Fontan operation.

\section{Introduction}

Patients with transposition of the great arteries after Senning/Mustard operation (TGA), those with corrected transposition of the great arteries (CCTGA) in whom a morphological right ventricle serves the systemic circulation and patients with common ventricular physiology after Fontan operation share special haemodynamic characteristics. The morphological right ventricle faces systemic circulation resistance, and thus works under

\author{
Corresponding author: \\ Olga Trojnarska, MD \\ $1^{\text {st }}$ Cardiology Department \\ University of Medical \\ Sciences Dluga $1 / 2$ \\ 61-848 Poznan, Poland \\ Phone: +48 618549146 \\ Fax: +48 618549094 \\ E-mail: olgatroj@wp.pl, \\ piotr@kardioserwis.pl
}


higher pressure afterload [1-6]. Single ventricle function in survivors of Fontan operation is highly dependent upon preload [7-9]. In these two clinical scenarios atrioventricular valve incompetence increasing during exercise leads to higher volume load of ventricles $[9,10]$. As a result such patients often develop heart failure [4, 5, 9, 10-14]. Adult patients with congenital heart disease (CHD), due to long-term adaptation, usually self-assess their exercise tolerance as satisfactory [15-19]. Objective evaluation of exercise capacity in such patients is of key importance since the introduction of appropriate treatment during the asymptomatic phase may improve outcomes in terms of heart failure symptoms, hospitalizations and mortality. The cardiopulmonary exercise test is a validated diagnostic and prognostic tool both in patients with left ventricular heart failure [20] and in those with selected CHD [15, 21-26]. Similar diagnostic and prognostic value of serum B-type natriuretic peptide (BNP) concentrations has been documented [20], including in adult patients with CHD in whom left [16, 27-29] or right ventricular [17, 18, 21, 30-34] function is impaired as a result of pressure or volume overload. However, we are not aware of any reports on relations between BNP levels and exercise capacity measured with the cardiopulmonary exercise test in a specific population of patients with a morphological right ventricle serving the systemic circulation or common ventricular physiology after Fontan operation.

The study aimed to evaluate exercise capacity using the cardiopulmonary exercise test in adult patients with a morphological right ventricle or single ventricle serving the systemic circulation, and levels of serum BNP in these patients, and to determine the relationship between BNP concentrations and cardiopulmonary exercise test parameters.

\section{Material and methods}

\section{Patients}

The study group included 40 patients (16 males) - 17 with transposition of the great arteries after Senning operation (TGA), 13 with corrected transposition of the great arteries (CCTGA) and
10 with a common ventricle after Fontan operation, aged $19-55$ years (mean $28.8 \pm 9.5$ years). TGA patients were operated on at the age of 1-14 years (mean $4.3 \pm 3.7$ years), 18-30 years earlier (mean $21.6 \pm 4.2$ years); 2 of them presented with small interatrial shunts. Of those with CCTGA 3 patients were operated on at the age of 11-33 years (mean $20.7 \pm 11.2$ years); in 1 a ventricular septal defect (VSD) was closed and tricuspid valvuloplasty was done, in another an atrial septal defect (ASD) was closed and the tricuspid valve was replaced with a mechanical prosthesis, and in the third both an ASD and VSD were closed and tricuspid valvuloplasty was carried out. The only other accompanying abnormality, found in 3 CCTGA subjects, was right ventricular outflow tract obstruction with pressure gradients not exceeding $50 \mathrm{~mm} \mathrm{Hg}$. Fontan operations in patients with common ventricular physiology were performed in subjects at the age of 5-14 years (mean 9.5 \pm 3.1 years), in all cases adopting the method of right atrial to pulmonary artery connections (Table I). Arterial blood oxygen saturation was $84-99 \%$ (mean $95.2 \pm 5.0 \%$ ) in the entire study group. The control group included 22 healthy individuals (10 males) aged 23-49 years (mean $30.6 \pm 6.1$ years). NYHA functional class was determined by a physician based on the assessment of patient's self-reported symptoms at the time of the exercise test. All study patients had sinus rhythm (subjects with atrial fibrillation/flutter were excluded), were free from arrhythmia and pulmonary disease and had serum creatine levels less than $140 \mu \mathrm{g} / \mathrm{ml}$ and glutamic oxaloacetic transaminase activity not exceeding twice the upper limit of normal.

\section{Measurement of serum BNP concentrations}

In all patients blood samples were drawn from an antecubital vein prior to the exercise test after a 15 min rest in supine position. Serum B-type natriuretic peptide concentrations were determined using immunoradiometric assay kit - Shionoria BNP (Schering CIS bio international). The radioactivity was measured for 1 min with gamma scintillation counter type NZ 335.

Table I. Demographic and clinical characteristics of analysed group of patients

\begin{tabular}{|lcccccc|}
\hline $\begin{array}{l}\text { Congenital } \\
\text { heart } \\
\text { disease }\end{array}$ & $\begin{array}{c}\text { Number of } \\
\text { patients }\end{array}$ & $\begin{array}{l}\text { Gender } \\
\% \text { male }\end{array}$ & $\begin{array}{c}\text { Age } \\
\text { [years] }\end{array}$ & $\begin{array}{c}\text { Number of } \\
\text { treated patients }\end{array}$ & $\begin{array}{c}\text { Age of } \\
\text { operation } \\
\text { [years] }\end{array}$ & $\begin{array}{c}\text { NYHA } \\
\text { class } \\
\text { I/II/III }\end{array}$ \\
\hline TGA-Senning & 17 & $7(41 \%)$ & $26.1 \pm 4.9$ & $17(100 \%)$ & $4.3 \pm 3.7$ & $15 / 2 / 0$ \\
\hline CCTGA & 13 & $6(46 \%)$ & $36.2 \pm 12.1$ & $3(23 \%)$ & $20.7 \pm 11.2$ & $6 / 7 / 0$ \\
\hline Fontan & 10 & $3(33 \%)$ & $23.8 \pm 3.1$ & $10(100 \%)$ & $9.5 \pm 3.1$ & $6 / 3 / 1$ \\
\hline
\end{tabular}

TGA-Senning - transposition of the great arteries after Senning operation, CCTGA - corrected transposition of the great arteries, Fontan - common ventricle after Fontan operation 


\section{Cardiopulmonary exercise test}

In all study patients a maximum, symptom-limited (fatigue and/or dyspnoea) treadmill exercise test according to modified Bruce protocol was performed (standard Bruce protocol with stage 0 added -3 min at $1.7 \mathrm{~km} / \mathrm{h}, 5 \%$ grading), whereas in control subjects standard Bruce protocol was used. Patients were encouraged to continue walking for as long as their respiratory quotient (RQ) exceeded 1 . The peak oxygen consumption (peak $\mathrm{VO}_{2}$ ), carbon dioxide production $\left(\mathrm{VCO}_{2}\right)$, and minute ventilation (VE) were measured using breath-by-breath gas analysis (Sensor Medics, model Vmax29). Before each test the system was calibrated with a standardized gas mixture. A standard 12-lead electrocardiogram was continuously recorded. Blood pressure was measured every 2 min using a cuff sphygmomanometer. Peak $\mathrm{VO}_{2}$ represents an average value measured during the last $20 \mathrm{~s}$ of exercise, and is expressed as $\mathrm{ml} / \mathrm{kg} / \mathrm{min}, \mathrm{ml} / \mathrm{min}$, and the percentage of predicted peak oxygen consumption. The ventilation/carbon dioxide slope $\left(\mathrm{VE} / \mathrm{VCO}_{2}\right.$ slope) was calculated automatically by the computer system of Vmax29. A spirometric study was performed in all subjects before the cardiopulmonary exercise test, providing measurement of forced vital capacity (FVC) and forced expiratory volume in $1 \mathrm{~s}\left(\mathrm{FEV}_{1}\right)$, which were expressed as percentage of predicted normal values

Table II. Comparison of BNP levels and spiroergometric parameters between studied group of patients and control group

\begin{tabular}{|c|c|c|c|}
\hline & $\begin{array}{l}\text { Study group } \\
\qquad N=40\end{array}$ & $\begin{array}{c}\text { Control group } \\
\qquad N=22\end{array}$ & $\begin{array}{c}\text { Value of } \\
p\end{array}$ \\
\hline Age [years] & $28.8 \pm 9.5$ & $30.3 \pm 6.1$ & 0.06 \\
\hline $\mathrm{BNP}[\mathrm{pg} / \mathrm{ml}]$ & $71.8 \pm 74.4$ & $10.7 \pm 8.1$ & 0.00001 \\
\hline $\begin{array}{l}\mathrm{VO}_{2} \\
{[\mathrm{ml} / \mathrm{kg} / \mathrm{min}]}\end{array}$ & $21.7 \pm 5.9$ & $34.1 \pm 7.2$ & 0.00001 \\
\hline $\mathrm{VO}_{2} \%$ & $54.7 \pm 11.3$ & $89.5 \pm 15.7$ & 0.00001 \\
\hline $\mathrm{VE} / \mathrm{VCO}_{2}$ & $34.8 \pm 7.1$ & $25.7 \pm 3.2$ & 0.00001 \\
\hline $\begin{array}{l}\text { HR max } \\
\text { [bpm] }\end{array}$ & $152.5 \pm 32.3$ & $187.2 \pm 15.6$ & 0.00001 \\
\hline $\mathrm{HR} \max \%$ & $80.9 \pm 16.3$ & $97.8 \pm 7.7$ & 0.00005 \\
\hline FVC [l] & $3.7 \pm 0.9$ & $4.6 \pm 0.3$ & 0.03 \\
\hline FVC \% & $95.5 \pm 14.4$ & $104.3 \pm 9.4$ & 0.04 \\
\hline $\mathrm{FEV}_{1}[\mathrm{l}]$ & $3.0 \pm 0.7$ & $3.7 \pm 0.9$ & 0.04 \\
\hline $\mathrm{FEV}_{1} \%$ & $79.8 \pm 29.9$ & $98.1 \pm 12.4$ & 0.0002 \\
\hline $\begin{array}{l}\text { BP max } \\
{[\mathrm{mm} \mathrm{Hg}]}\end{array}$ & $161.5 \pm 20.3$ & $174.6 \pm 12.3$ & 0.04 \\
\hline $\mathrm{RQ}$ & $1.0 \pm 0.04$ & $1.1 \pm 0.06$ & 0.0005 \\
\hline
\end{tabular}

$B N P$ - brain natriuretic peptide, $V_{2}$ - peak oxygen consumption, $V E / V C O_{2}$ slope - ventilatory equivalent for carbon dioxide, FVC - forced vital capacity, $F E V_{1}$ - forced expiratory volume in $1 \mathrm{~s}, B P$ max - peak exercise blood pressure, HR max - peak exercise heart rate, $R Q$ - respiratory quotient adjusting for age, sex and body mass. The evaluation of the cardiopulmonary exercise tests was performed by investigators blinded to the results of BNP measurements.

\section{Statistical analysis}

Continuous variables following a normal distribution were expressed as mean and standard deviation, those not normally distributed as median and range. Variables following a normal distribution were compared using Student's t-test for unpaired samples. Otherwise the Mann-Whitney U test was used. For comparisons involving more than two groups ANOVA with Tukey post-hoc test following Shapiro-Wilk test for normality and Leven's test for homogeneity of variance or Kruskal-Wallis test with Dunn's multiple comparisons test were used.

To assess the degree of correlation between variables, Spearman's rank correlation or Pearson's correlation coefficient (depending on variable distribution) was used. Results are presented as the coefficient of correlation $(r)$. $P$ value $<0.05$ was considered significant. Statistical analysis was carried out using Statistica software ver. 8.

Informed consent was obtained from each patient and the study protocol conforms to the ethical guidelines of the 1975 Declaration of Helsinki as reflected in a priori approval of the institution's human research committee.

\section{Results}

The majority of patients, 27 (67.5\%), selfreported their exercise capacity as satisfactory and accordingly were classified as NYHA class I; 12 patients (30\%) reported mild intolerance of exercise and were classified as NYHA class II; and only 1 patient (0.5\%) after Fontan operation presented with symptoms of heart failure class III.

Heart failure symptoms were observed in 2 patients (12\%) with TGA, 7 (54\%) with CCTGA, and $4(40 \%)$ with a single ventricle following Fontan surgery.

\section{Cardiopulmonary exercise test parameters}

As shown in Table II, the peak $\mathrm{VO}_{2}$ was lower in the study group than in the control group $(p=0.00001)$. Maximum heart rate at peak exercise (HRmax) was also lower in the study group than in healthy individuals ( $p=0.00001$, Table II). A significant difference was also observed for the respiratory workload parameter $\mathrm{VE} / \mathrm{VCO}_{2}$ slope, which was higher in the study group vs. the control group ( $p=0.00001$, Table II). Among studied patients the systolic blood pressure at peak exercise was lower than in the control group ( $p=0.04$, Table II). Main respiratory quotient (RQ) in the 
analysed patients was significantly lower than in the control group ( $p=0.0005$, Table II).

\section{Spirometric study}

Parameters of pulmonary elasticity FVC and FVC\% were significantly lower in patients with analysed congenital heart disease than in healthy controls ( $p=0.03, p=0.04$ respectively, Table II). Moreover, $\mathrm{FEV}$ and $\mathrm{FEV}_{1} \%$, reflecting airway obstruction, were also significantly reduced in study patients compared to healthy subjects ( $p=0.04$ and $p=0.0002$; respectively, Table II).

Mean BNP level was higher in study patients than in the control group ( $p=0.00001$, Table II). No correlations were found between BNP concentrations and results of cardiopulmonary exercise tests, age of the patients at the time of CHD surgical correction or current age. In NYHA class I patients mean BNP level of $13.5 \pm 8.6 \mathrm{pg} / \mathrm{ml}$ was significantly lower than $145.1 \pm 86.3 \mathrm{pg} / \mathrm{ml}$ in NYHA class II patients ( $p=0.00001)$, but similar to that in healthy controls $(10.9 \pm 8.2 \mathrm{pg} / \mathrm{ml})$.

\section{Discussion}

Most study patients with a morphological RV serving the systemic circulation and those after Fontan operation were asymptomatic; only one third of them reported moderate exercise intolerance. The European Heart Survey, a large European registry including adult patients with congenital heart disease [19], reports similar results in patients with a morphological right ventricle serving the systemic circulation and worse exercise tolerance in patients with common ventricle physiology after Fontan operation, which is reduced in $60 \%$ of them. Better exercise capacity than in our study is reported occasionally in patients with atrial switch operated TGA and CCTGA [30]. However, long-term follow-up studies reveal that by the $4^{\text {th }}$ decade of life over $50 \%$ of patients with CCTGA develop heart failure [1, 2], and $25-88.5 \%$ of patients 25 years after Senning/Mustard operation for TGA present severe heart failure symptoms [4, 5]. Our results are similar to those of Piran et al. [8], who reported symptoms of heart failure in $22 \%$ of atrial switch operated TGA patients, $32 \%$ of patients with CCTGA and $40 \%$ of patients after Fontan operation. Cardiopulmonary exercise test, providing objective assessment of exercise capacity, revealed its significant reduction in study patients. A discrepancy between favourable self-reported tolerance of exercise and reliable measures of exercise capacity resulting from long-term adaptation in such patients, similar to that observed in other types of congenital heart disease, has been reported previously by our team [16-18, 35], as well as by other investigators [15]. The main cause of heart failure in study patients appears to be dysfunction of a morphological right ventricle serving the systemic circulation. Using contrastenhanced magnetic resonance imaging Giardii et al. [24] documented structural and functional RV abnormalities in patients with CCTGA and atrial switch operated TGA subjects. They observed extensive fibrosis resulting most likely from inadequate perfusion of hypertrophic myocardium and probably also from insufficient myocardial protection during cardiac surgery in the past. These myocardial changes lead to reduced contractility of a morphological RV serving the systemic circulation. Patients with a common ventricle after Fontan operation have diminished cardiac output despite having only marginal ventricular dysfunction, which is mainly due to the absence of the pulmonary ventricle [9]. In patients with a morphological right ventricle or single ventricle serving the systemic circulation, atrioventricular valve incompetence increasing during exercise leads to significant volume overload of ventricles [2, 8, 9, 35]. Cardiac output in patients after Mustard/Senning operation for TGA and especially in patients after Fontan operation is highly dependent on preload. In the former situation it is mainly the result of low atrial buffalo compliance $[4,10]$. In the latter one passive ventricular filling depends on venous pressure $[7,11]$.

Our study, consistently with results reported by other investigators [15, 23, 36, 37], confirmed the significant role of pulmonary dysfunction in the development of heart failure in adult patients with CHD. Patients in our study presented with spirometric abnormalities consistent with impaired pulmonary elasticity as well as airway obstruction resulting most likely from prior surgery with lung scarring, diaphragmatic palsy, atelectasis and cardiomegaly [15, 36, 37].

We have shown that in patients with a morphological right ventricle serving the systemic circulation and common ventricle physiology after Fontan operation maximal heart rate at peak exercise is reduced as compared to healthy adults. Similar observations in patients with CCTGA were made by Friedriksen et al. [37], and by Nozori et al. [26] in an unselected group of adult patients with congenital heart disease of whom many underwent Mustard/Senning operation for TGA. However, this was not confirmed by Canadian investigators [30]. According to Gillian et al. [6] lower heart rate at peak exercise in patients with TGA after atrial switch operation may represent an adaptive mechanism facilitating ventricular filling via noncompliant atrial buffalo. Similar observations suggesting clinical relevance of an impaired chronotropic response in adult heart failure patients with congenital heart disease have been reported 
by others $[15,23,26]$. A team of investigators from Royal Brompton Hospital [37] has shown chronotropic incompetence to be a risk factor of death in such patients [38]. Finding that 15 patients ( $37.5 \%$ of the study group) failed to reach $80 \%$ maximum predicted age-adjusted heart rate at peak exercise, which is believed to worsen the prognosis, may reflect potential risks in our study population [38]. This rate is similar to that reported by Norozi et al. [26], who studied a group including patients with complex cyanotic heart disease and those with Fontan physiology, but still significantly higher than in patients with ischaemic heart disease (11\%) or dilated cardiomyopathy (25\%) [39].

Another diagnostic and prognostic factor in heart failure is B-type natriuretic peptide [1, 20, 21, 33]. We have found significantly increased serum concentrations of BNP in patients with a morphological RV serving the systemic circulation and in those after Fontan operation. Similar findings were reported by Laarsen et al. [40]. Higher BNP levels were also documented in patients with a right ventricle serving the systemic circulation in a population including many subjects with CCTGA, atrial switch operated TGA and after Fontan operation [29]. Limited reports on BNP levels in patients with common ventricle physiology after Fontan operation are inconsistent. Ohuhi et al. [14] found increased concentrations of BNP only in symptomatic patients, especially in subjects operated on using atrio-pulmonary connection, presenting with a markedly enlarged right atrium, where natriuretic peptide is produced. Of note, all patients after Fontan operation in our study were survivors of such procedures. Increased serum BNP levels in patients after Fontan operation were reported by Inai et al. [9]. Like us, they also did not find a significant correlation between BNP concentration and peak oxygen uptake during cardiopulmonary exercise testing. They also failed to provide evidence for a prognostic role of serum BNP level during 4-year follow-up. In contrast, Law et al. [27] did not find a significant increase of serum BNP levels in patients after Fontan operation who presented with clinical symptoms and haemodynamic evidence of heart failure. Such equivocal findings on BNP levels probably result from complex pathophysiology of heart failure in the studied patients. Although, as reported by others, BNP concentrations were higher in patients in more advanced NYHA functional classes [23, 29, 40], they did not correlate with results of cardiopulmonary exercise testing. BNP release has been documented to be mainly dependent upon myocardial wall stress resulting from pressure and volume overload [16-18, 21, 27-29, 30-34]. In study patients reduced preload, attenuating BNP production in the heart, is an additional factor contributing to heart failure. According to the results of our study and previously published reports serum BNP level has no diagnostic value in patients with a right ventricle serving the systemic circulation or common ventricle physiology.

In conclusion, patients with a morphological right ventricle serving the systemic circulation and with common ventricle physiology after Fontana operation show markedly reduced exercise capacity. They are also characterized by higher serum concentrations of BNP, which do not however correlate with cardiopulmonary exercise test parameters.

\section{References}

1. Graham TP, Bernard YD, Mellen BG, et al. Long-term outcome in congenitally corrected transposition of the great arteries: a multi-institutional study. J Am Coll Cardiol 2000; 36: 255-61.

2. Beauchesne LM, Warnes CA, Connolly HM. Outcome of the unoperated adult who present with congenitally corrected transposition of the great arteries. J Am Coll Cardiol 2002; 40: 285-90.

3. Puley G, Siu S, Connolly M, et al. Arrhythmia and survival in patients $>18$ years of age after the Mustard procedure for complete transposition of the great arteries. Am J Cardiol 1999; 83: 1080-6.

4. Ross-Hesselink JW, Meijboom FJ, Spitaels SE, et al. Decline in ventricular function and clinical condition after Mustard repair for transposition of the great arteries (a prospective study of 22-29 years). Eur Heart J 2004; 25: 1264-70.

5. Moons P, Gewlong M, Sluysmans T, et al. Long term outcome up to 30 years after the Mustard or Senning operation: a nationwide multicenter study in Belguim. Heart 2004; 90: 307-13.

6. Gilliam T, Eriksson BP, Sixt R. Cardiac output and pulmonary gas exchange at maximal exercise after atrial redirection for complete transposition of the great arteries. Eur Heart J 1998; 19: 1856-64.

7. Bolger AP, Gatzoulis MA. Towards defining heart failure in adults with congenital heart disease. Int J Cardiol 2004; 97 (Suppl 1): 15-23.

8. Piran S, Veldtman G, Siu S, Webb GD, Liu PP. Heart failure and ventricular dysfunction in patients with single or systemic right ventricle. Circulation 2002; 105: 1189-94.

9. Inai K, Nakanishi T, Nakazawa M. Clinical correlation and prognostic predictive value of neurohormonal factors in patients late after the Fontan operation. Am Heart J 2005; 150: 588-94.

10. Dos L, Teruel L, Ferreira IJ, et al. Late outcome after Senning and Mustard procedures for correction of transposition of the great arteries. Heart 2005; 91: 625-56.

11. Dimopoulos K, Diller GP, Piepoli MF, Gatzoulis MA. Exercise intolerance in adults with congenital heart disease. Cardiol Clin 2006; 24: 641-60.

12. Warnes CA. The adults with congenital heart disease. Born to be bad? J Am Coll Cardiol 2005; 46: 1-8.

13. Connelly MS, Liu PP, Williams WG, Webb GD, Robertson P, McLaughlin PR. Congenitally corrected transposition of the great arteries in the adults: functional status and complications. J Am Coll Cardiol 1996; 27: 1238-43.

14. Ohuchi $H$, Takasugi $H$, Ohashi $H$, et al. Abnormalities of neurohormonal and cardiac autonomic nervous activities relate poorly to functional status in Fontan patients. Circulation 2004; 110: 2601-8. 
15. Fredriksen PM, Veldtman G, Hechter S, et al. Aerobic capacity in adults with various congenital heart disease. Am J Cardiol 2001; 87: 310-4.

16. Trojnarska O, Gwizdala A, Lanocha M, et al. Cardiopulmonary exercise testing in the evaluation of exercise capacity and B-type natriuretic protein level in adult patients after repair of coarctation of aorta. Tex Heart Inst J 2007; 34: 412-9.

17. Trojnarska O, Szyszka A, Gwizdala A, et al. Evaluation of exercise capacity with cardiopulmonary exercise testing and with type $B$ natriuretic peptide concentration in adults patients with patent atrial septal defect. Cardiology 2006; 106: 154-62.

18. Trojnarska O, Szyszka A, Gwizdala A, et al. The BNP concentration and exercise capacity assessment with cardiopulmonary stress test in patients after surgical repair of Fallot's tetralogy. Int J Cardiol 2006; 110: 86-92.

19. Engelfriet $P$, Boersma E, Oechslin E, et al. The spectrum of adult congenital heart disease in Europe: morbidity and mortality in a 5 years follow-up period. The Euro Heart Survey on adult congenital heart disease. Eur Heart J 2005; 26: 2325-33.

20. Wedberg K, Cleland J, Dargie H, et al. Task Force for the Diagnosis and Treatment of Chronic Heart Failure of the European Society of Cardiology. Guidelines for the diagnosis and treatment of chronic heart failure: executive summary (update 2005): The Task Force for the Diagnosis and Treatment of Chronic Heart Failure of the European Society of Cardiology. Eur Heart J 2005; 26: 1115-40.

21. Book WM, Hott BJ, McConnel M. B-type natriuretic peptide levels in adults with congenital heart disease and right ventricular failure. Am J Cardiol 2005; 95: 545-6.

22. Glaser S, Opitz CF, Bauer U, et al. Assessment of symptoms and exercise capacity in cyanotic patients with congenital heart disease. Chest 2004; 125: 368-76.

23. Diller GP, Dimopoulos K, Okonko D, et al. Exercise intolerance in adult congenital heart disease: comparative severity, correlates, and prognostic implication. Circulation 2005; 112: 828-35.

24. Giardini A, Lovato L, Donti A, et al. Relation between right ventricular structural alterations and markers of adverse clinical outcome in adults with systemic right ventricle and either congenital complete (after Senning operation) or congenital corrected transposition of the great arteries. Am J Cardiol 2006; 98: 1277-82.

25. Ohuchi H, Watanabe K, Kishiki K, Wakisako Y, Echigo S. Heart rate dynamics during and after exercise in postoperative congenital heart disease patients. Their relation to cardiac autonomic nervous activity and intrinsic sinus node dysfunction. Am Heart J 2007; 154: 165-71.

26. Norozi K, Wessel A, Cand VA, et al. Chronotropic incompetence in adolescents and adults with congenital heart disease after cardiac surgery. J Card Fail 2007; 13: 263-8.

27. Law YM, Keller BB, Feingold BM, Boyle GJ. Usefulness of plasma B-type natriuretic peptide to identify ventricular dysfunction in pediatric and adult patients with congenital heart disease. Am J Cardiol 2005; 95: 474-8.

28. Cowley CG, Bradley JD, Shaddy RE. B-type natriuretic peptide levels in congenital heart disease. Pediatr Cardiol 2004; 25: 336-40.

29. Bolger AP, Sharma R, Lei W, et al. Neurohormonal activation and chronic heart failure syndrome in adults with congenital heart disease. Circulation 2002; 106: 92-9.

30. Dore A, Houde C, Chan KL, et al. Angiotensin receptor blockade and exercise capacity in adults with systemic right ventricle: a multicenter, randomized, placebocontrolled clinical trial. Circulation 2005; 112: 2411-6.

31. Yap LB. B-type natriuretic peptide and right heart. Heart Fail Rev 2004; 9: 99-103.

32. Oosterhof T, Tulewski II, Vliegen HW, Spijkerboer O, Mudler BJ. Effects of volume and/or pressure overeload secondary to congenital heart disease (tetralogy of Fallot or pulmonary stenosis) on right ventricular function using cardiovascular magnetic resonance and B-type natriuretic peptide levels. Am J Cardiol 2006; 97: 1051-5.

33. Yap LB, Ashrafian H, Mukerjee D, Coghlan JG, Timms PM. The natriuretic peptides and their role in disorders of right heart dysfunction and pulmonary hypertension. Clin Biochem 2004; 37: 847-56.

34. Cheung EW, Lam WW, Chiu CS, Chau AK, Cheung SC, Cheung Y. Plasma brain natriuretic peptide levels, right ventricular volume overeload and exercise capacity in adolescens after surgical repair of tetralogy of Fallot. Int J Cardiol 2007; 121: 155-62.

35. Trojnarska O, Szyszka A, Gwizdala A, et al. Adults with Ebstein anomaly-cardiopulmonary exercise testing and BNP level. Int J Cardiol 2006; 111: 92-7.

36. Giardini A, Scecchia S, Berton E, et al. Strong and independent prognostic value of peak circulatory power in adults with congenital heart disease. Am Heart J 2007; 154: 441-7.

37. Fredriksen PM, Chen A, Veldtman G, Hechter S, Therrien J, Webb G. Exercise capacity in adult patients with congenitally corrected transposition of the great arteries. Heart 2001; 85: 191-5.

38. Diller GP, Dimopoulos K, Okonko D, et al. Heart rate response during exercise predicts survival in adults with congenital heart disease. J Am Coll Cardiol 2006; 48: 1250-6.

39. Lauer MS, Francis GS, Okin PM, Pashkow FJ, Snader CE, Marvock TH. Impaired chronotropic response to exercise stress test as a prior of mortality. JAMA 1999; 281: 524-9.

40. Larsson DA, Meurling CJ, Holmqvist F, Waktare JE, Thilen UJ. The diagnostic and prognostic value of brain natriuretic peptides in adults with a systemic morphologically right ventricle or Fontan-type circulation. Int J Cardiol 2007; 114: 345-51. 